\title{
INCREASE OF THE OPERATING LIFE OF ACTIVE PARTS OF COLD-MOULDING TOOLS
}

\author{
Ján Moravec
}

Original scientific paper Heat treatment of active components of cold - moulding tools is a necessary operation to guarantee their functionality. The tools made by this method loose the required quality of durability and period of service and losses caused by their frequent exchange are high. One way we can stop it is by coating the active parts of pressing tools by thin, hard and abrasion resistant deposit that is suitable by definite method of the tool stress.

Keywords: Cold-moulding tool; EDAX analysis; Hardness; PVD coating; TiCN

Povećanje radnog vijeka aktivnih dijelova alata za oblikovanje na hladno

Izvorni znanstveni članak

Toplinska obrada aktivnih dijelova alata za oblikovanje na hladno je neophodan postupak kojim se garantira njihova funkcionalnost. Alati izrađeni na taj način gube potrebnu kvalitetu trajnosti i izdržljivosti te dolazi do velikih gubitaka zbog njihove česte zamjene. Način da se to zaustavi je oblaganje aktivnih dijelova alata za tiješnjenje tankom, tvrdom i na abraziju otpornom prevlakom odgovarajućom metodom naprezanja alata.

Ključneriječi: alat za oblikovanje na hladno; EDAX analiza; tvrdoća; PVD prevlaka; TiCN

\section{Introduction}

After Slovakia's accession to the EU, the opportunities for quality vacuum heat treatment of high alloy tool steels in heat treatments companies with precise direction and control of the upgrading process for the producers of the moulding tools have increased. Every year about one million tons of steel and 200 million tons of plastic are produced and processed. A big part of these materials is processed by moulding tools on which new and higher requirements are being placed:

- Accuracy, because of ever-increasing speeds of processing and loading there is a need to produce flawless details with ever tighter tolerances and thinner walls.

- Complete production on a single tool.

- Processing in dry and with minimal lubricating resulting in cost savings, reducing costs for cleaning of workpieces and machines and the reduction of environmental burden.

- Improved quality of product to minimize the need for additional work and the amount of scrap.
This forces us to seek more efficient methods that help eliminate losses. One possibility is the coating of dies by a thin, hard and abrasion-resistant layer, which is specific for the particular type of loading tool.

\section{Coatings and their properties}

Processing technologies of depositions on surfaces of materials to improve their properties have been used for several decades. In the beginning, the chemical coating was used in the gas phase. This method is carried out under high temperature deposition (about $1000{ }^{\circ} \mathrm{C}$ ), when the heat is affecting surface structure of the coated material, and therefore, its use is limited primarily on sintered carbides. The development of physical and plasma chemical methods done at about $500{ }^{\circ} \mathrm{C}$ allowed coating of conventional tool steels.

The functionality of the temperature of the deposition and the deposition thickness for certain methods of deposition is shown in Fig. 1. The depositions that are most used in practice for the improvement of the properties of the active part of the tools are shown in Tab. 1 and examples for production are presented in Tab. 2.

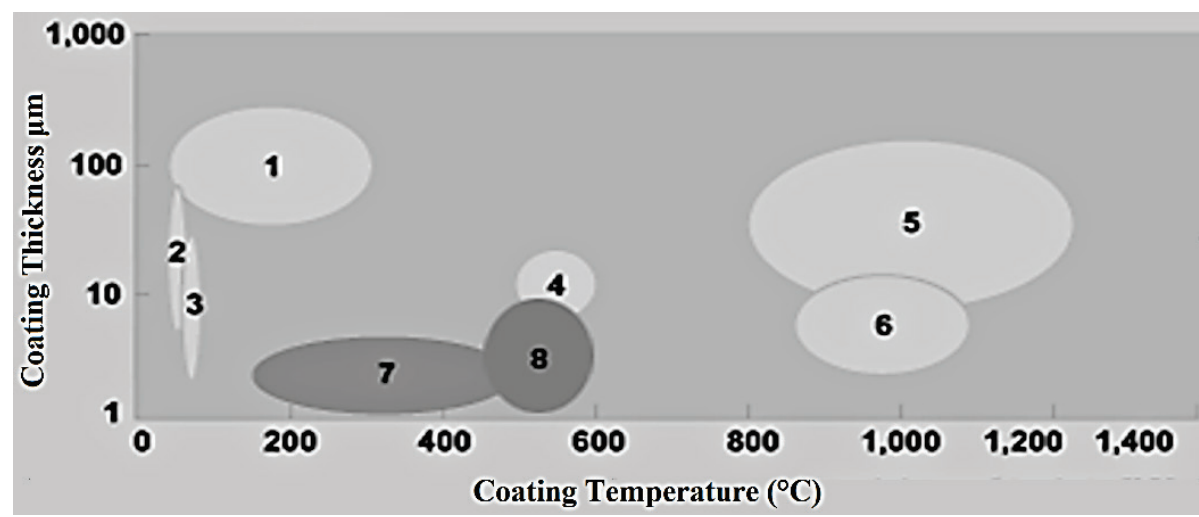

Figure 1 Functionality of the temperature of the deposition and the deposition thickness [1]: 1 - plasma spraying, 2 - Electrolyitic and chemical deposition, 3 - phosphating, 4 - nitriding, 5 - boronising, 6 - CVD (CVD = Chemical Vapour Deposition), 7 - PVD a PACVD (PVD = Physical Vapour Deposition), PACVD = Plasma Assisted Chemical Vapour Deposition), 8 - P3e $\mathrm{e}^{\mathrm{TM}}\left(\mathrm{P} 3 \mathrm{e}^{\mathrm{TM}}=\right.$ Pulse Enhanced Electron Emission) 
Table 1 The selected parameters of the depositions

\begin{tabular}{|c|c|c|c|c|c|c|c|}
\hline Deposition & Structure & Colour & Thickness $/ \mu \mathrm{m}$ & $\begin{array}{c}\text { Microhardness } \\
(0,05 \mathrm{HV}) / 1\end{array}$ & $\begin{array}{c}\text { Coefficient of } \\
\text { friction }\end{array}$ & $\begin{array}{c}\text { Process } \\
\text { temperature }\end{array}$ & $\begin{array}{c}\text { Max. service } \\
\text { temperature }\end{array}$ \\
\hline TiN & monolayer & gold & $1 \div 5$ & 2300 & 0,4 & $<500$ & 600 \\
\hline TiCN & gradient & grey & $1 \div 4$ & 3000 & 0,4 & $<500$ & 400 \\
\hline TiAlN & multilayer & purple & $1 \div 4$ & 3000 & 0,4 & $<500$ & 800 \\
\hline CrN & monolayer & metallic & $1 \div 4$ & 1750 & 0,4 & $<500$ & 700 \\
\hline PLC & gradient & grey & $<1$ & $1200 \div 2000$ & $0,15 \div 0,2$ & $<500$ & 300 \\
\hline
\end{tabular}

Table 2 Examples for productions

\begin{tabular}{|l|l|l|}
\hline \multicolumn{1}{|c|}{ Workpiece material } & \multicolumn{1}{c|}{ Punching } & \multicolumn{1}{c|}{ Forming } \\
\hline Steel $<>10^{3} \mathrm{MPa}$ & TiCN, TiN & TiCN, TiN \\
\hline Steel $45 \div 65 \mathrm{HRC}$ & TiCN & TiCN \\
\hline Stainless steel & AITiN+PLC & AITiN+PLC \\
\hline $\mathrm{Al}, \mathrm{Al}$ alloys & AITiN $(\mathrm{PLC}), \mathrm{CrN}$ & AITiN+PLC, CrN \\
\hline $\mathrm{Cu}, \mathrm{Cu}$ alloys & $\mathrm{CrN}, \mathrm{CrC}$ & $\mathrm{CrN}, \mathrm{C}$ \\
\hline
\end{tabular}

\section{Choose the appropriate brand of the cold-moulding tool steel}

Quality of the steel is given predominantly by the origin, the primary and secondary metallurgy or the subsequent treatment in the solid state (forming, annealing). For materials of the same brand, but supplied by two various producers and supply companies, differences in hardenability can attain more than $10 \%$ in wear resistance of the order of tens of percent and as for toughness these differences may vary up to several times.
Cleanliness of metallurgical processes for the production of steel and finishing surfaces of tools or tool design can have a major impact on performance of tools. The technology of metallurgical processing of steel is graded according to the quality and purity of the final product, from conventional metallurgy to powder metallurgy [2]. Examples of cold-moulding tool steel by various methods of metallurgical processing are given in Tab. 3.

Table 3 Examples of tool steels for cold - mould working [3]

\begin{tabular}{|c|c|c|c|c|c|c|c|c|}
\hline \multirow{2}{*}{ Brand of Steel } & \multirow{2}{*}{ Metallurgical processing } & \multicolumn{5}{|c|}{ The content of chemical elements (\%) } \\
\cline { 3 - 8 } & & $\% \mathrm{C}$ & $\% \mathrm{Si}$ & $\% \mathrm{Mn}$ & $\% \mathrm{Cr}$ & $\% \mathrm{Mo}$ & $\% \mathrm{~W}$ & $\% \mathrm{~V}$ \\
\hline 1.2379 & conventional & 1,55 & 0,30 & 0,40 & 11,80 & 0,80 & - & 0,80 \\
\hline Caldie & ESR - ElectroslagRemelting & 0,60 & 0,35 & 0,80 & 5,30 & - & - & 0,20 \\
\hline Vanadis 4 & PM - Powder Metallurgy & 1,50 & 1,00 & 0,50 & 8,00 & 1,50 & - & 4,00 \\
\hline
\end{tabular}

\section{Experimental part}

We have examined the effect of using of TiCN deposition coated PVD method onto a substrate - tool steel Vanadis 4, hardened on secondary hardness 5860 HRC (Figs. 2. and 3.). Material for punching was used from sheets of material CuNi25 with strength $90 \mathrm{HV} 30$.

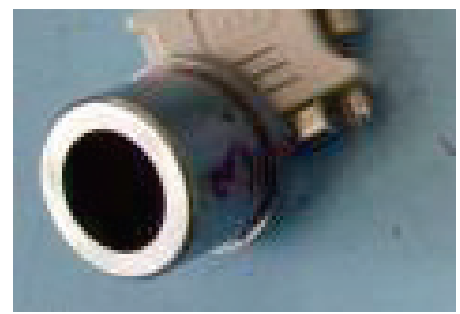

Figure 2 Sample Nr. 1 - Cutting die

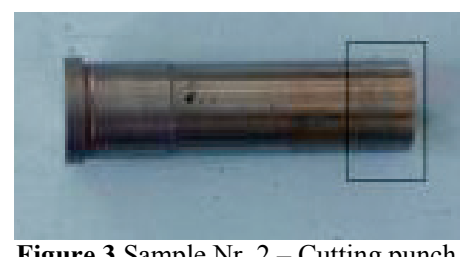

Figure 3 Sample Nr. 2 - Cutting punch

\subsection{Chemical analysis of the substrate}

Chemical analysis of the substrate was done by the method GDOES. The choice of the analytical method was based on the dimensional and geometric options of evaluated material. The results of chemical analysis of the substrate are shown in Tab. 4.

Table 4 Results of chemical analysis of the substrate

\begin{tabular}{|c|c|c|}
\hline \multirow{2}{*}{ Element } & \multicolumn{2}{|c|}{ The content of chemical elements (\%) } \\
\cline { 2 - 3 } & Sample Nr. 1 & Sample Nr. 2 \\
\hline $\mathrm{C}$ & 1,45 & 1,47 \\
\hline $\mathrm{Mn}$ & 0,36 & 0,37 \\
\hline $\mathrm{Si}$ & 0,61 & 0,56 \\
\hline $\mathrm{P}$ & 0,023 & 0,023 \\
\hline $\mathrm{S}$ & 0,016 & 0,019 \\
\hline $\mathrm{Cr}$ & 6,85 & 6,91 \\
\hline $\mathrm{Mo}$ & 1,50 & 1,45 \\
\hline $\mathrm{V}$ & 3,64 & 3,60 \\
\hline
\end{tabular}

\subsection{Chemical analysis of the deposition}

Chemical analysis of coating was done by the method EDAX. The choice of the analytical method was based on the dimensional and geometric options of evaluated material. EDAX analysis results of coating are reported in Figs. 4 and 5, and in Tabs. 5 and 6. 


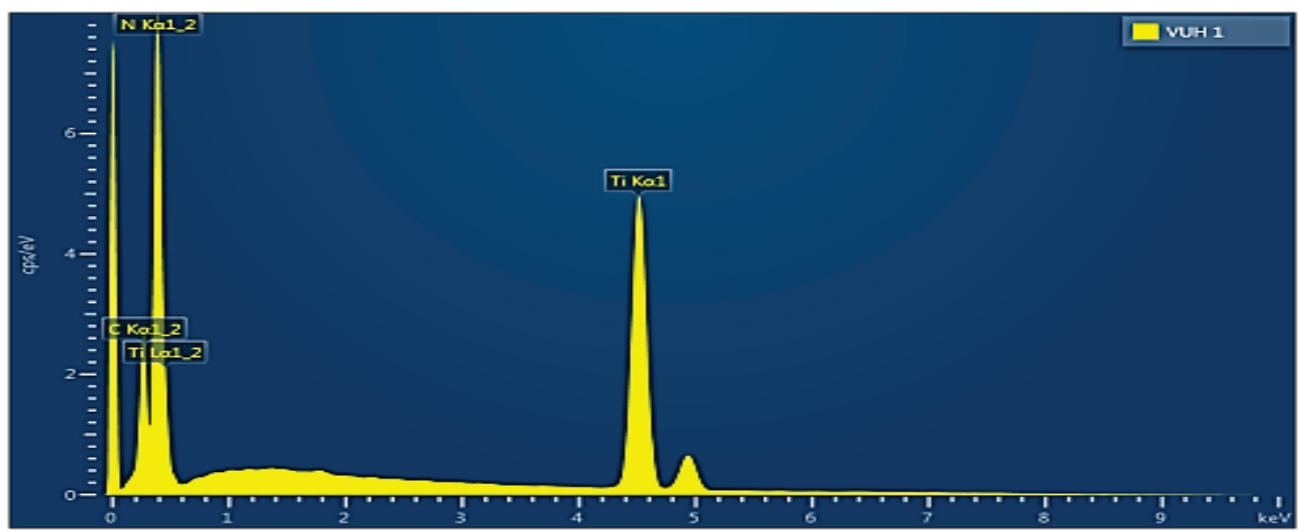

Figure 4 Chart of EDAX analysis of sample No. 1

Table 5 Table of EDAX analysis of sample No. 1

\begin{tabular}{|c|c|c|c|c|}
\hline Element & Line Type & wt.\% & wt.\% Sigma \\
\hline $\mathrm{C}$ & K series & 7,13 & 0,14 \\
\hline $\mathrm{N}$ & K series & 14,86 & 0,23 \\
\hline $\mathrm{Ti} \quad$ Total: & & 78,01 & 0,25 \\
\hline
\end{tabular}

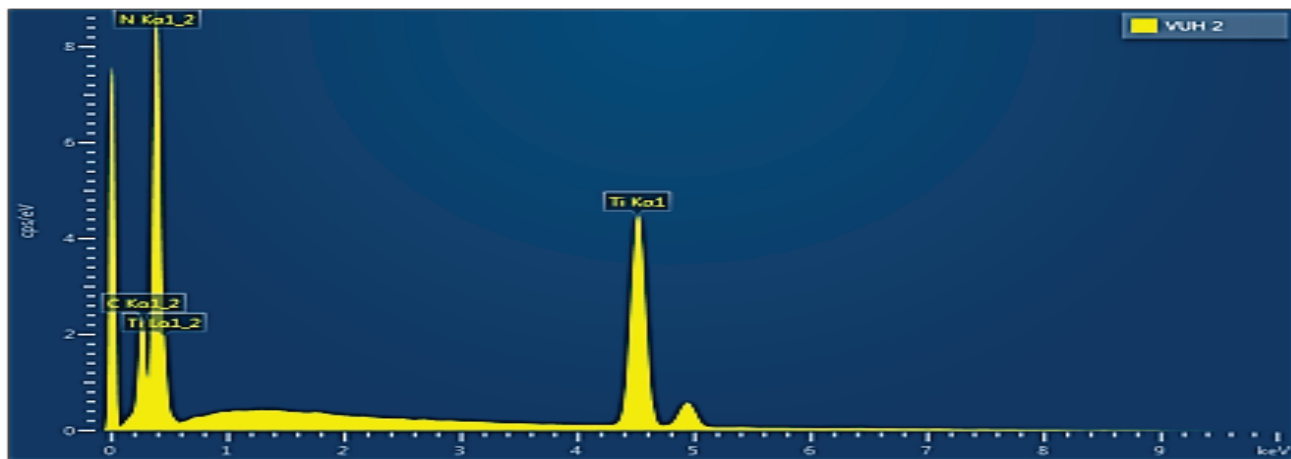

Figure 5 Chart of EDAX analysis of sample No. 2

Table 6 Table of EDAX analysis of sample No. 2

\begin{tabular}{|c|c|c|c|c|}
\hline Element & Line Type & wt. $\%$ & wt.\% Sigma & 0,14 \\
\hline $\mathrm{C}$ & K series & 6,60 & 15,99 \\
\hline $\mathrm{N}$ & K series & 18,54 & 0,24 \\
\hline $\mathrm{Ti}$ & K series & 74,86 & 0,26 \\
\hline
\end{tabular}

\subsection{Hardness of the substrate}

Hardness of the substrate was done by methodology Vickers HV60, in accordance with ISO 6507-1. Measurement results are presented in Tab. 7. The results represent the arithmetic average of three individual measurements.

Table 7 Hardness of substrate

\begin{tabular}{|c|c|}
\hline Marking of samples & Hardeness HV60 \\
\hline Sample 1 & 797 \\
\hline Sample 2 & 738 \\
\hline
\end{tabular}

\subsection{Microhardness of the deposition}

Measurement of microhardness of the deposition in accordance with ISO 6507-1 - both on the surface and the cross-sectional view - could not be done due to the very small thickness of the coating, because there would be a complete penetration of the layer (from surface measurements), or overlapping of the measuring injection of the deposition to the substrate (measured in crosssection).

For this reason, it had to be done by the hardness measurement method known as "Nanoindentation" using the corresponding hardness testers CSM Instruments. All positions of performed measurements of microhardness of the depositon under nanoindentation were located in the working part of the samples. The measurement results are presented in Tab. 8. It represents the mean value of the 15 indentations, which have been done, and the variability of the results is the coefficient of variation of the series of results.

Table 8 Hardness measuring of deposition - nanoindentation

\begin{tabular}{|c|c|}
\hline Marking of samples & Hardness HV \\
\hline Sample 1 & $3210 \pm 14 \%$ \\
\hline Sample 2 & $2992 \pm 22 \%$ \\
\hline
\end{tabular}

\subsection{Experiment results}

To produce the cutting punch and die we used the substrate - cold - moulding tool steel as the base material, 
known commonly as Vanadis 4 - the special tool steel produced by the method of PM from Uddeholm. Active parts were hardened and tempered to secondary hardness in vacuum hardening furnace. Chemical analysis of the substrate by the method GDOES is given in Tab.4. The final hardness of the substrate is shown in Tab. 7 .

In the first part of the experiment, we produced about 75000 strokes with prepared active components without coating on the material CuNi25 of strength 90 HV 30 until the end of life of the active parts. In the second part of the experiment, we used the active components using deposition of TiCN deposited by PVD on a substrate - the above-described tool steel hardened to secondary hardness $58 \div 60$ HRC. Chemical analysis of deposition and the graphical representation of the percentage of the elements referred to in paragraph 4.2 and microhardness of the coating is shown in Tab. 8. With these modified components, we have reached 1,5 million strokes until the end of their operating life, which is a 20 -fold increase in service life of active components of the tool.

\section{Conclusion}

We pointed out in the article that the appropriate choice of the coating method, layer and structure of the deposition for the mode of stress can significantly improve the properties of the active components of the cold - moulding tools, which is reflected in particular in a several fold increase in durability of tools. The forming tools are characterized by the fact that their active components are usually produced of high alloy tool steels and their profile is complicated, with strict dimensional tolerances. PVD method has been successfully used in coating technology for this type of active components of cold - moulding tool because it retains all the desired properties. With DLC or PLC layers we are improving these properties. Currently mainly combinations of CVD and PVD or nanostructured coatings, which imply further improvement characteristics of cold-moulding tools, are gaining more and more importance.

\section{References}

[1] URL: www.oerlikobalzers.cz. (13.05.2015)

[2] Uddeholm.Tooling solutions for advanced high strength steel. Uddeholm Tooling and SSAB Swedish Steel, 2004.

[3] Uddeholm. Brochure from Boehler - Uddeholm Slovakia, 2009.

[4] Hosford, W. F.; Caddel, R. M. Metal Forming, Mechanics and Metallurgy. Cambridge University Press, 2011. DOI: 10.1017/CBO9780511976940

[5] Kumar, S. Technology of Metal Forming Processes. New Delhi, India, 2008

[6] Marciniak, Z.; Duncan, J. L.; Hu, S.J. Mechanics of Sheet Metal Forming. Butterworth-Heinemann, Jordan hill, Oxford, 2002.

[7] Mielnik, M.E. Mechanical Metallurgy. Mc Graw-Hill Book Company, New York, 1991.

[8] MetalForming Handbook, Springer Verlag, Berlin, 2010

[9] Moravec, J. Forming Tools. University of Žilina. Edis 2011.

[10] Stanislav, J. Tepelné spracování materiálů pro formy na tlakové lití. Trenčín, 2003.
[11] Prostinák, Š. Zvyšovanie trvanlivosti nástrojov povlakovaním. Trnava, 1995.

[12] Bláhová, O. Hodnocení vlastností tenkých vrstev TiCn. Jihlava, 2006.

\section{Authors' addresses}

Ján Moravec, doc. Ing., PhD.

University of Žilina, Faculty of Mechanical Engineering,

Department of Technological Engineering

Univerzitná 1, 01026 Žilina, Slovakia

jan.moravec@fstroj.uniza.sk 